\title{
LLNL Superconducting Magnets Test Facility
}

N. Martovetsky, R. Manahan, J. Moller, J. Zbasnik

This article was submitted to

$16^{\text {th }}$ International Conference on Magnet Technology

Ponte Vedra Beach, Florida

September 26 - October 2, 1999

\section{September 16, 1999}

U.S. Department of Energy

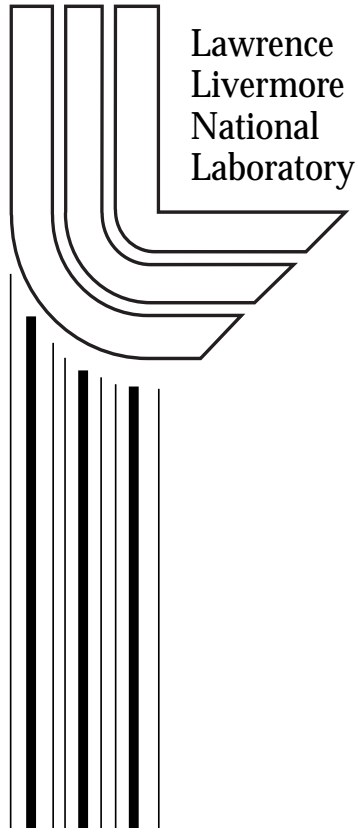




\section{DISCLAIMER}

This document was prepared as an account of work sponsored by an agency of the United States Government. Neither the United States Government nor the University of California nor any of their employees, makes any warranty, express or implied, or assumes any legal liability or responsibility for the accuracy, completeness, or usefulness of any information, apparatus, product, or process disclosed, or represents that its use would not infringe privately owned rights. Reference herein to any specific commercial product, process, or service by trade name, trademark, manufacturer, or otherwise, does not necessarily constitute or imply its endorsement, recommendation, or favoring by the United States Government or the University of California. The views and opinions of authors expressed herein do not necessarily state or reflect those of the United States Government or the University of California, and shall not be used for advertising or product endorsement purposes.

This is a preprint of a paper intended for publication in a journal or proceedings. Since changes may be made before publication, this preprint is made available with the understanding that it will not be cited or reproduced without the permission of the author.

This report has been reproduced directly from the best available copy.

Available to DOE and DOE contractors from the

Office of Scientific and Technical Information

P.O. Box 62, Oak Ridge, TN 37831

Prices available from (423) 576-8401

http:/ / apollo.osti.gov/bridge/

Available to the public from the National Technical Information Service

U.S. Department of Commerce 5285 Port Royal Rd., Springfield, VA 22161 http://www.ntis.gov/

OR

Lawrence Livermore National Laboratory Technical Information Department's Digital Library http://www.llnl.gov/tid/Library.html 


\title{
LLNL Superconducting Magnets Test Facility
}

\author{
N. Martovetsky, R. Manahan, J.Moller \\ Lawrence Livermore National Laboratory, Livermore, CA, USA \\ J. Zbasnik \\ Lawrence Berkeley National Laboratory, Berkeley, CA, USA
}

\begin{abstract}
The FENIX facility at Lawrence Livermore National Laboratory was upgraded and refurbished in 1996-1998 for testing CICC superconducting magnets. The FENIX facility was used for superconducting high current, short sample tests for fusion programs in the late 1980-s -early 1990-s. The new facility includes a 4-m diameter vacuum vessel, two refrigerators, a $40 \mathrm{kA}, 42 \mathrm{~V}$ computer controlled power supply, a new switchyard with a dump resistor, a new helium distribution valve box, several sets of power leads, data acquisition system and other auxiliary systems, which provide a lot of flexibility in testing of a wide variety of superconducting magnets in a wide range of parameters.

The detailed parameters and capabilities of this test facility and its systems are described in the paper.
\end{abstract}

Index Terms-Facility, superconducting magnet, CIC conductors, testing

\section{INTRODUCTION}

The FENIX test facility was constructed at LLNL to support the development of high current conductors for fusion, particularly, for the ITER machine. The facility had the capability to test conductors in a magnetic field up to $13.5 \mathrm{~T}$ and with transport currents up to $40 \mathrm{kA}$. The detailed description of the facility is given in [1]. In 1994 the facility was moth balled. In $1996-1998$ we rebuilt the facility for testing superconducting magnets with cable-in-conduit (CIC) conductors. A new power supply, a new switch yard, $40 \mathrm{kA}$ vapor cooled leads, a distribution cold box and transfer lines were added and integrated into the facility.

The facility was successfully used for testing a SMES model coil in collaboration with Toshiba Corporation in 1998.

Nicolai Martovetsky, e-mail:martovetsky1@llnl.gov, fax: (925) 4222477

\section{SYSTEM OVERVIEW}

The facility consist of two refrigerators, which produce liquid and supercritical helium at $4.5 \mathrm{~K}$, helium distribution system, complete closed gas management system, power supply, protection system, data acquisition systems and auxiliary systems.

The main parameters of the facility are listed in Table 1.

Table 1. Main parameters of the LLNL Superconducting magnets test facility

\begin{tabular}{|c|c|}
\hline SYSTEM & PARAMETERS \\
\hline Refrigeration & $\begin{array}{l}2 \text { refrigerators } 400 \mathrm{~W} \text { at } \\
4.5 \mathrm{~K} \text { or } 1401 / \text { hour } \\
\text { combined } \\
\text { up to } 23 \mathrm{~g} / \mathrm{s} \text { supercritical } \\
\text { helium }\end{array}$ \\
\hline Liquid helium storage & $9000 \mathrm{LHe}$ tank \\
\hline Gas management system & $\begin{array}{l}\text { Complete package- } \\
\text { dryers, purifiers, storage }\end{array}$ \\
\hline Power supplies & $\begin{array}{l}\text { 1. } 40 \quad \mathrm{kA}, \quad 42 \mathrm{~V} \\
\text { computerized control } \\
\text { 2. } 5 \mathrm{kA}, 12 \mathrm{~V} \\
\text { 3. } 10 \mathrm{kA}, 12 \mathrm{~V}\end{array}$ \\
\hline Vacuum vessel & $\begin{array}{l}4.1 \mathrm{~m} \text { ID, } 6.6 \mathrm{~m} \text { tall, } \\
\text { LN2 shielded }\end{array}$ \\
\hline Data acquisition system & $\begin{array}{l}144 \text { channels, } \\
\text { isolation amplifiers }\end{array}$ \\
\hline
\end{tabular}

A layout of the experimental hall is shown in Fig.1.

\section{REFRIGERATION SYSTEM}

The refrigeration system at LLNL facility consists of two refrigerators and auxiliary systems - gas and liquid distribution, gas handling, purification, cooling, vacuum, etc.

The Airco refrigerator has about $180 \mathrm{~W}$ of refrigeration at $4.5 \mathrm{~K}$ and higher and mass flow up to $23 \mathrm{~g} / \mathrm{s}$ of supercritical 


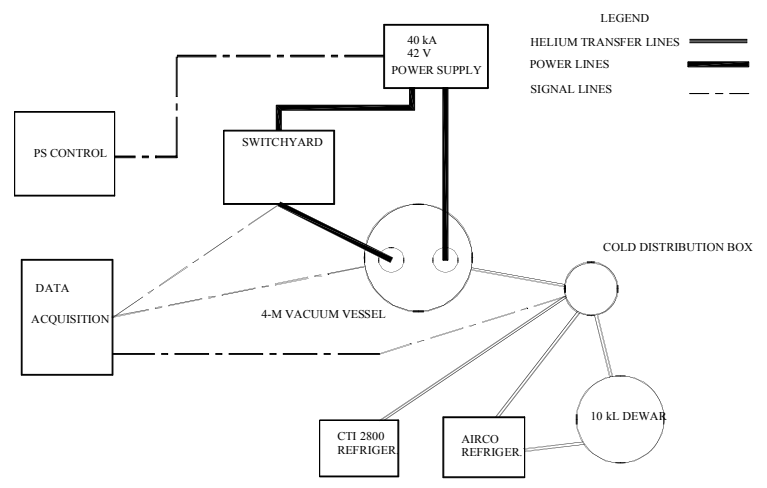

Fig.1 LLNL Superconducting magnet testing facility

helium at maximum pressure of 12.5 bar. In liquefaction mode it produces about $60 \mathrm{l} /$ hour.

The CTI 2800 is used mainly as a liquefier with $801 /$ hour capacity. In refrigeration mode it has the power of $220 \mathrm{~W}$ at $4.5 \mathrm{~K}$.

The LLNL facility has a distribution cold box to provide very flexible options for the magnet refrigeration with supercritical and liquid helium at different mass flow rates, inlet temperatures and pressures.

\section{POWER SUPPLY}

A new, 1.7 MW DC, $40.5 \mathrm{kA},+/-42 \mathrm{~V}$ two quadrant power supply was procured and installed in 1998. The power supply has a $0.1 \%$ regulation accuracy for both voltage and current output. It can work with inductive loads in a wide range of parameters.

Computer control allows for a wide range of the waveforms, including single or a train of rectangular or trapezoidal pulses, complex pulses with several flat tops, etc.

The ripple of current in the power supply is very low, which makes it very convenient for testing the superconducting magnets.

\section{PROTECTION SYSTEM}

A schematic of the protection system and controls are shown in Fig. 2.

The protection system consists of a dump resistor, two circuit breakers and two power switches.

The switches are capable of carrying the DC current, but can not break the circuit at high voltage. The circuit breakers for $40 \mathrm{kA} \mathrm{DC}$ are not commercially available. We used commercially available components to build a reliable protection system. When quench is detected in the superconducting magnet, the power switches open first and then with a $0.5 \mathrm{~s}$ delay, the circuit breakers open an the energy is dissipated in the dump resistor. Using two switches and two breakers reduces the probability of a fault dramatically.

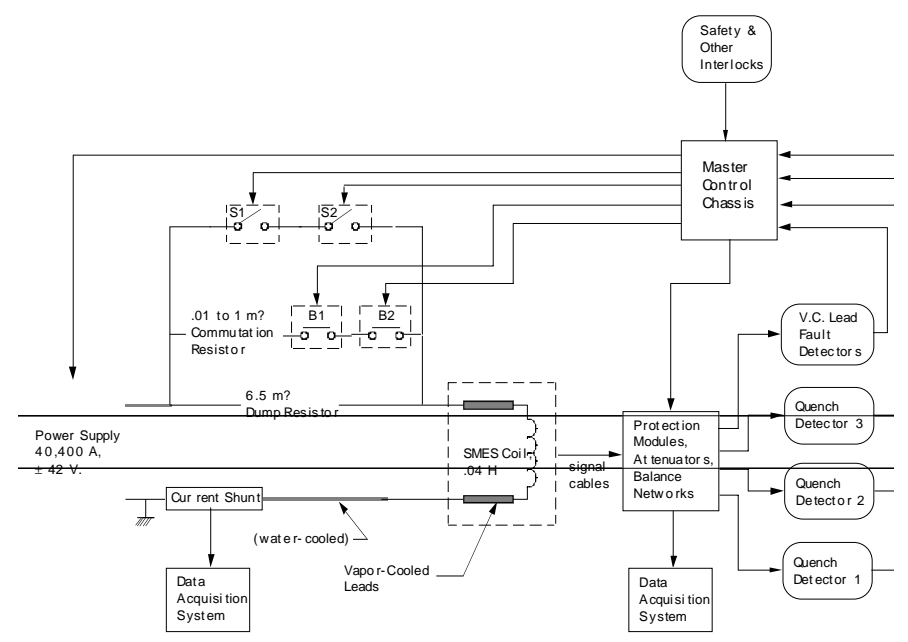

Fig.2 Protection system schematic

The protection system was configured for testing the 40 $\mathrm{mH}, 40 \mathrm{kA}$ superconducting SMES Model Coil [2]. It is capable of evacuation of the stored energy of $32 \mathrm{MJ}$ at 40 kA current and $300 \mathrm{~V}$. The system can be easily upgraded to $800 \mathrm{~V}$ maximum discharge voltage.

The dump resistor was designed to heat up to about $200 \mathrm{C}$. The material of the resistor is low carbon steel. When resistor heats up, resistance increases and this makes evacuation of the stored energy more efficient than if resistance would have been unchanged during protective discharge.

\section{VACUUM VESSEL}

The usable volume for testing in the vacuum vessel is $4.1 \mathrm{~m}$ in diameter and about $6 \mathrm{~m}$ high. The vessel has LN2 shields covering about $60 \%$ of the inner surface and $40-\mathrm{kA}$ vapor cooled leads.

There are 4 helium gas cooled columns in the vessel, capable of supporting more than $50 \mathrm{t}$ of the dead weight of the tested object.

Fig. 3 shows a $3.7-\mathrm{m}$ coil [2] inside the vacuum vessel.

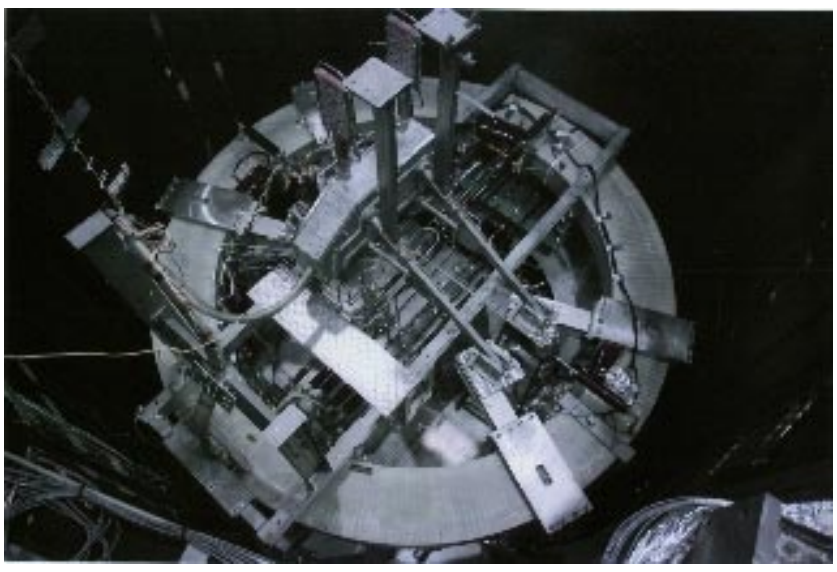

Fig.3 A SMES model coil installed in the test facility 


\section{40 KA VAPOR COOLED POWER LEADS}

We built $40 \mathrm{kA}$ vapor cooled leads for testing the SMES model coil. Each vapor-cooled lead has a conventional copper lead and a superconducting bus inside a long $3.5 \mathrm{~m}$ can, filled with liquid helium. The level of helium in the can is maintained automatically by a level sensor.

\section{DATA ACQUISITION SYSTEM}

The data acquisition system at LLNL facility can process 144 channels of data. There are 96 isolation amplifiers with isolation voltages from 300 to $1000 \mathrm{~V}$.

The bandwidth of the main data system is from fraction of a Hertz to $10 \mathrm{~Hz}$.

There is also an additional fast data acquisition system, which can take 16 channels of transients with up to $1 \mathrm{MHz}$ frequency.

\section{CONCLUSION}

The LLNL superconducting magnets testing facility provides a complete set of subsystems for testing the superconducting magnets in a wide range of parameters. The facility was successfully used in 1998 by testing a 40 kA $32 \mathrm{MJ}$ coil in wide variety tests.

\section{ACKNOWLEDGEMENT}

We are grateful to $\mathrm{K}$. Thomassen for his support in the facility upgrade. We are thankful to our collaborators and sponsors from Toshiba corporation: K. Matsutani, M. Tesuka, S. Hanai and their co-workers for their support and contributions into the facility upgrade. Work performed for DOE by LLNL under contract No. W-7405-Eng-48.

\section{REFERENCES}

[1] D.S.Slack, R.E. Patrick, J.R. Miller, "FENIX, a Test Facility for ITER”, IEEE Trans. On Mag. 27, 1839 (1991)

[2] Satoshi Hanai, Yoshihiro Wachi, Mamoru Shimada, et al,"Cyclic and Mechanical Test Results of the 100kWh SMES Model Coil", this conference 